\title{
THE EFFECTS OF OXYGEN, NITROGEN, AND CARBON DIOXIDE STEEPING REGIMES ON ENDOSPERM MODIFICATION AND EMBRYO GROWTH OF GERMINATING BARLEY SEEDS
}

\author{
by \\ GREGORY C. GIBBONS \\ Department of Biotechnology, Carlsberg Research Laboratory, \\ Gamle Carlsberg Vej 10, DK-2500 Copenhagen Valby
}

Keywords: Water uptake, malting, calcofluor, cytolytic enzymes.

\begin{abstract}
A study has been made of the effects of $\mathrm{O}_{2}, \mathrm{~N}_{2}, \mathrm{CO}_{2}$, and air treatment during steeping of two varieties of barley, Nordal from Denmark and Tokak from Turkey. Steeping time was varied from 1 to 3 days and the seeds subsequently germinated on sand for 7 days. Water uptake, endosperm modification (measured as cell wall breakdown), and embryo growth (measured as root and shoot growth) were monitored throughout germination.

The results showed that steeping in the presence of pure $\mathrm{O}_{2}$ and $\mathrm{CO}_{2}$ were toxic and inhibited subsequent water uptake, modification, and embryo growth. Anaerobic steeping in the presence of $\mathrm{N}_{2}$ had little inhibitory effect on these three parameters when compared to steeping in well aerated water. It is confirmed that removal of $\mathrm{CO}_{2}$ from grains during steeping is more important than addition of oxygen.
\end{abstract}

\section{INTRODUCTION}

The malting of barley may be defined as a large scale germination of the individual seeds under controlled conditions. For practical reasons malting is normally carried out in two distinct phases: 1) a steeping phase, in which the grain is immersed in water to achieve a rapid and even start for the physiological changes desired within the grain, and 2) a germination phase, in which the rehydrated grain proceeds to effect the major internal changes involved in the germination process.

It has long been acknowledged that the actual steeping conditions used (i.e. balance between oxygen and carbon dioxide tensions in the microenvironment of the grain, temperature, final moisture content) play an important role in the quality of the final malt after germination $(4,5$, $6,7,15,16,18,19,20$ ).

The development of fluorescence staining techniques specially designed to measure the extent of endosperm modification in individual germinating seeds and populations of these $(3,8$, $9,10,11,17)$, prompted therefore a study of changes occurring both inside germinating seeds 
and in their embryos as a result of different treatments during steeping. The present communication describes the effects of oxygen, nitrogen, carbon dioxide, and air during steeping on endosperm modification, water uptake, and embryo growth as measured by root and shoot development.

\section{MATERIALS AND METHODS}

\subsection{Seed material}

Two varieties of barley (Hordeum vulgare L.) were used in this study. Nordal, from the 1980 harvest at the Carlsberg Research Farm, Allindemaglegàrd, Denmark, and Tokak (a spring barley variety sown in the fall) from the 1981 crop in the Anatolian highlands of Turkey, obtained via Türk Tuborg Bira ve Malt Sanayii A.S., Izmir, Turkey.

Seeds were size classified using a Mini Petkus sorting machine (Schule, Hamburg, West Germany) and the fraction retained between 2.85 $\mathrm{mm}$ and $3.00 \mathrm{~mm}$ was stored at room temperature and used for all experiments.

\subsection{Steeping}

Steeping was carried out at $15^{\circ} \mathrm{C} .250-350 \mathrm{~g}$ seed were placed in 11 Erlenmeyer flasks containing $350-400 \mathrm{ml}$ sterile distilled water. The desired gas was passed through the water via a sparger at a pressure of 0.05 bar which resulted in a gentle agitation of the seeds and saturation of water with the gas in question. Steeping was carried out for 24 hours, 48 hours, and 72 hours as required. Oxygen, carbon dioxide, and nitrogen were obtained from AGA Denmark in compressed gas bottles. Atmospheric air was obtained from the oil- and moisture-free central laboratory compression system at the Carlsberg Research Center.

\subsection{Germination}

Following steeping the seeds were blotted free of excess surface moisture and 70 seeds pressed into sterile sand $(100 \mathrm{~g})$ in a sterile petri dish to which $21 \mathrm{ml}$ sterile distilled water was then added. Germination was allowed to proceed for 1 to 7 days at $15{ }^{\circ} \mathrm{C}$ in a darkened, refrigerated cabinet at $98 \%$ relative humidity.

\subsection{Moisture analysis}

Following germination, seeds were removed from the sand by washing, blotted free of surface moisture and following drying at $80{ }^{\circ} \mathrm{C}$ for 20 hours, the moisture content was determined.

\subsection{Root and shoot measurement}

Root and shoot length were measured manually following removal of the seeds from the sand and classified as follows: Class $0=$ no visible root or shoot; $1=1-10 \mathrm{~mm}$ long; $2=11-20 \mathrm{~mm} ; 3$ $=21-30 \mathrm{~mm} ; 4=31-40 \mathrm{~mm} ; 5=41-50 \mathrm{~mm} ; 6=51$ $60 \mathrm{~mm} ; 7=$ greater than $60 \mathrm{~mm}$.

\subsection{Measurement of malt modification}

The germinated seeds were dried as above (2.4), embedded into blocks of cernit and cut into half seeds as described by HeLtved et al. (14) using a commercial Carlsberg Seed Fixation System obtained from this laboratory. Malt modification based on cell wall breakdown in longitudinally cut half seeds was measured using the Calcofluor method described by AASTRUP et al. (3) in a commercial Malt Modification Analyser - System Carlsberg, also obtained from this laboratory. Modification of the individual seeds was expressed as a Modification Class: Class $0=$ unmodified; $1=0-20 \%$ modified; $2=20-40 \%$ modified; $3=40-60 \%$ modified; $4=60-80 \%$ modified; $5=80-95 \%$ modified; $6=95-99 \%$ modified; $7=$ $100 \%$ modified.

\section{RESULTS}

\subsection{1 day steeping}

Following 1 day of steeping, all treatments took up the same amount of water in the case of Nordal (Figure 1) while in the variety Tokak the $\mathrm{CO}_{2}$-treated seeds absorbed slightly more water than the other treatments (Figure 2). It was observed that the absolute level of water uptake for Nordal was higher than for Tokak. During 7 days of germination there was little difference between treatments with Nordal while in Tokak, $\mathrm{CO}_{2}$-treatment resulted in a lower final water content of seeds.

The modification pattern for the case of Nordal showed that $\mathrm{CO}_{2}$-treatment during 1 day of steeping had an inhibitory effect on both the rate and the eveness of modification during 7 days of germination (Figure 7). The air- and $\mathrm{N}_{2}$-treat 
NORDAL 1DAY STEEP

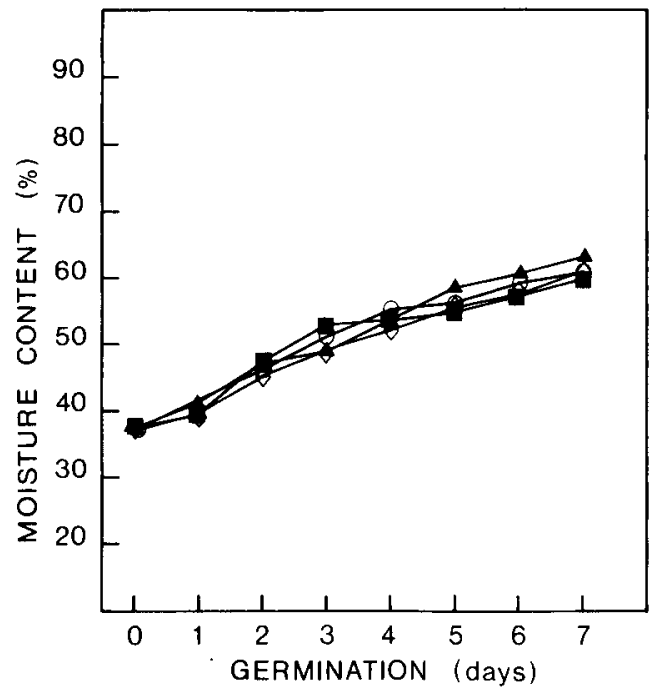

Figure 1. Water uptake in seeds of Nordal barley steeped for 1 day at $15^{\circ} \mathrm{C}$ under the following conditions:

$\Delta$ constant aeration with atmospheric air; $O$ constant bubbling of nitrogen in the steep; constant bubbling of oxygen in the steep; $\square$ constant bubbling of carbon dioxide in the steep.

TOKAK 1 DAY STEEP

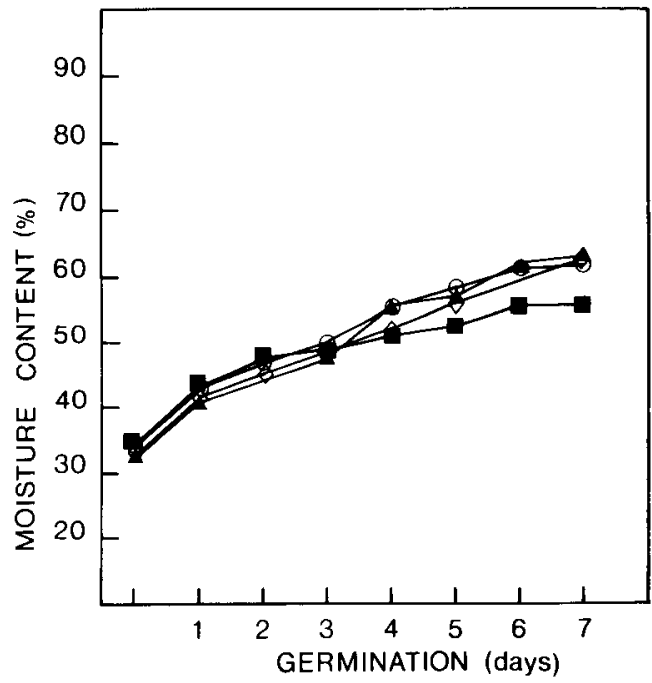

Figure 2. Water uptake in seeds of Tokak barley steeped for 1 day at $15^{\circ} \mathrm{C}$ under the conditions described in Figure 1.
NORDAL 2DAYS STEEP

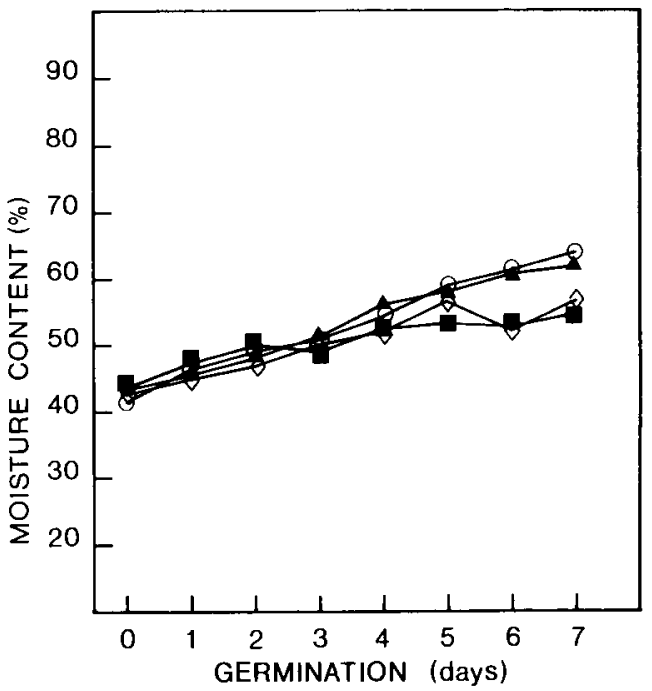

Figure 3. Water uptake in seeds of Nordal barley steeped for 2 days at $15^{\circ} \mathrm{C}$ under the conditions described in Figure 1.

TOKAK 2DAYS STEEP

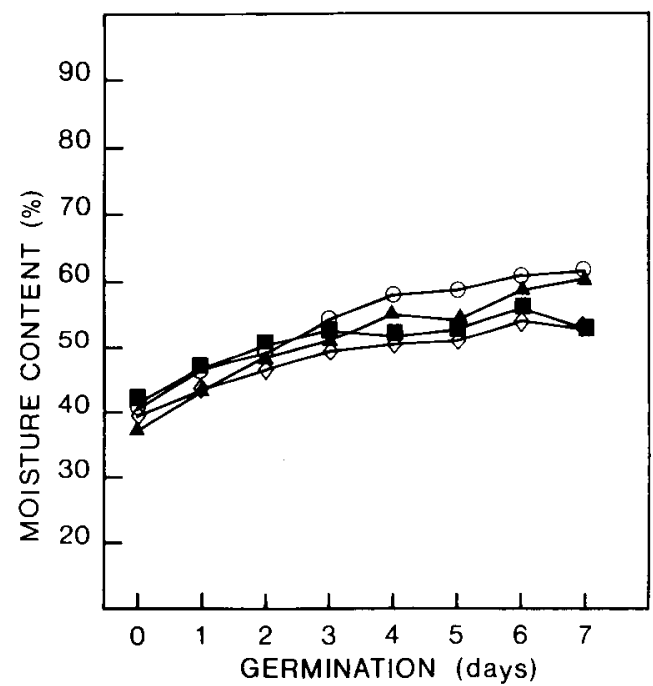

Figure 4. Water uptake in seeds of Tokak barley steeped for 2 days at $15^{\circ} \mathrm{C}$ under the conditions described in Figure 1. ments resulted in a similar pattern of modification for Nordal as seen with unsteeped seeds of this variety in earlier experiments $(8,9)$, and the $\mathrm{O}_{2}$-treatment showed a slightly lower rate of initial modification.
Embryo growth in Nordal, as measured by the development of roots and shoots, indicated very little difference between the treatments.

Turning to the variety Tokak, the modification process started more slowly following $\mathrm{CO}_{2}$ - 
NORDAL 3DAYS STEEP

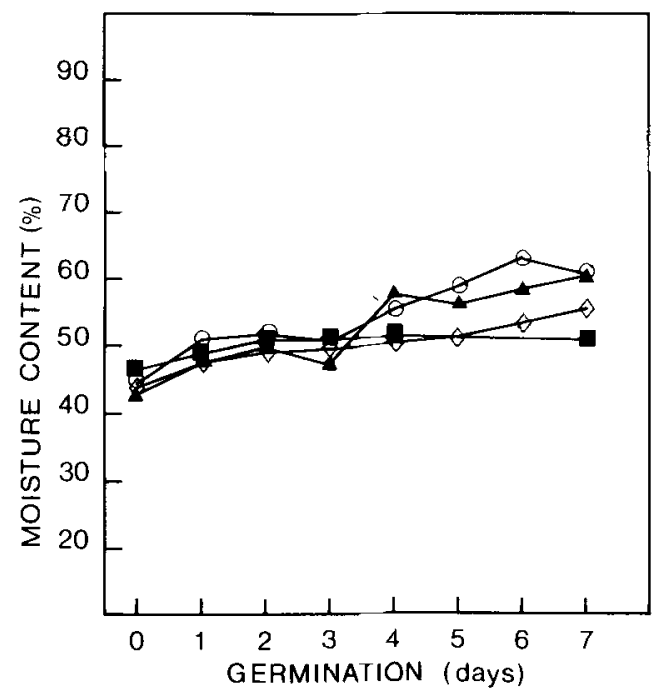

Figure 5. Water uptake in seeds of Nordal barley steeped for 3 days at $15^{\circ} \mathrm{C}$ under the conditions described in Figure 1.

treatment (Figure 9). With this variety, the bubbling of pure $\mathrm{O}_{2}$ during the steep appeared also to have some inhibitory effect on modification.

Embryo growth of Tokak was clearly inhibited by both $\mathrm{O}_{2}$ and $\mathrm{CO}_{2}$ during the 1 day steeping period. It is interesting to note that root and shoot development is considered to involve a large degree of cell expansion and as such requiring a high water uptake for these processes. The water uptake data for Tokak (Figure 2) clearly showed while there was less final water uptake for the $\mathrm{CO}_{2}$-treatment, no difference was observed in the case of $\mathrm{O}_{2}$-treatment, even though this treatment resulted in less embryo growth.

\subsection{2 days steeping}

2 days steeping resulted in higher initial moisture content than 1 day for both Nordal (Figure 3) and Tokak (Figure 4) in all treatments. In both varieties it was observed that $\mathrm{CO}_{2}$-treatment resulted in the highest initial moisture content of the seeds. In the subsequent period of germination in air, however, $\mathrm{CO}_{2}$-steeping inhibited overall water uptake in both varieties. 2 days steeping with $\mathrm{O}_{2}$ showed a similar inhibitory effect on the total water uptake to that seen with $\mathrm{CO}_{2}$.

The initial out-of-steep modification was greatest for the $\mathrm{O}_{2}$-treated seeds but subsequently
TOKAK JOAYS STEEP

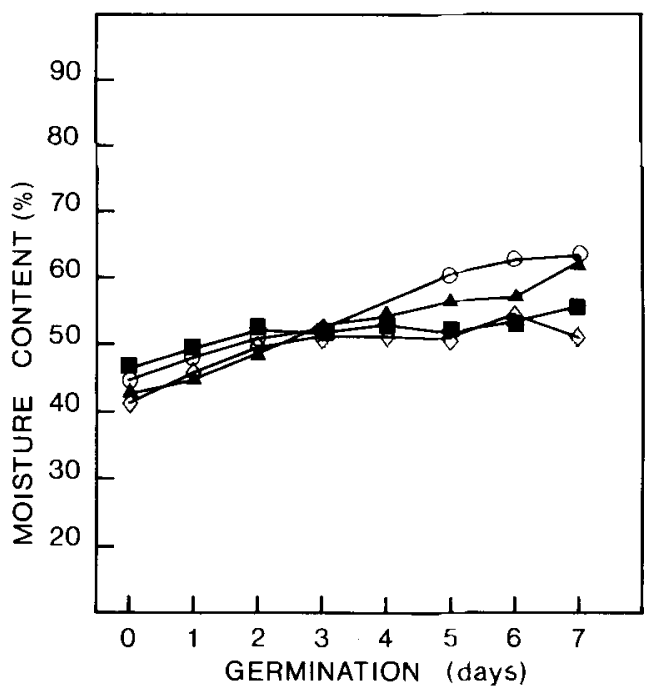

Figure 6. Water uptake in seeds of Tokak barley steeped for 3 days at $15^{\circ} \mathrm{C}$ under the conditions described in Figure 1.

both $\mathrm{O}_{2}$ - and $\mathrm{CO}_{2}$-steeped Nordal exhibited a slower and more uneven internal modification. Steeping in the presence of $\mathrm{O}_{2}$ brought about the greatest final inhibition of modification.

$\mathrm{N}_{2}$ showed an inhibition in the rate of modification to a lesser extent than $\mathrm{O}_{2}$ and $\mathrm{CO}_{2}$.

Root development with Nordal was initially more rapid in seeds steeped with $\mathrm{O}_{2}$ and atmospheric air. Later during germination, clear inhibition of both root and shoot growth was seen as a result of both $\mathrm{O}_{2}$ - and $\mathrm{CO}_{2}$-steeping (Figure 12). Inhibition was greatest with the $\mathrm{O}_{2}$ steeped seeds. $\mathrm{N}_{2}$ in the steep showed no apparent effect on embryo development when compared to steeping in air.

$\mathrm{O}_{2}$-treated Tokak was more modified out of steep than the other treatments (Figure 13). $\mathrm{O}_{2}$ steeping, however, inhibited further modification of the endosperm. $\mathrm{CO}_{2}$ again showed a marked inhibition of modification. There was little difference between the $\mathrm{N}_{2-}$ and atmospheric air treatment although a slight inhibition was seen around the $5^{\text {th }}$ and $6^{\text {th }}$ day of germination for the $\mathrm{N}_{2}$-steeped seeds.

As was seen with Nordal, $\mathrm{O}_{2}$ - and air-treated Tokak showed most initial root development (Figure 14). Later in germination, however, $\mathrm{O}_{2}$ steeping again showed the greatest inhibition of 


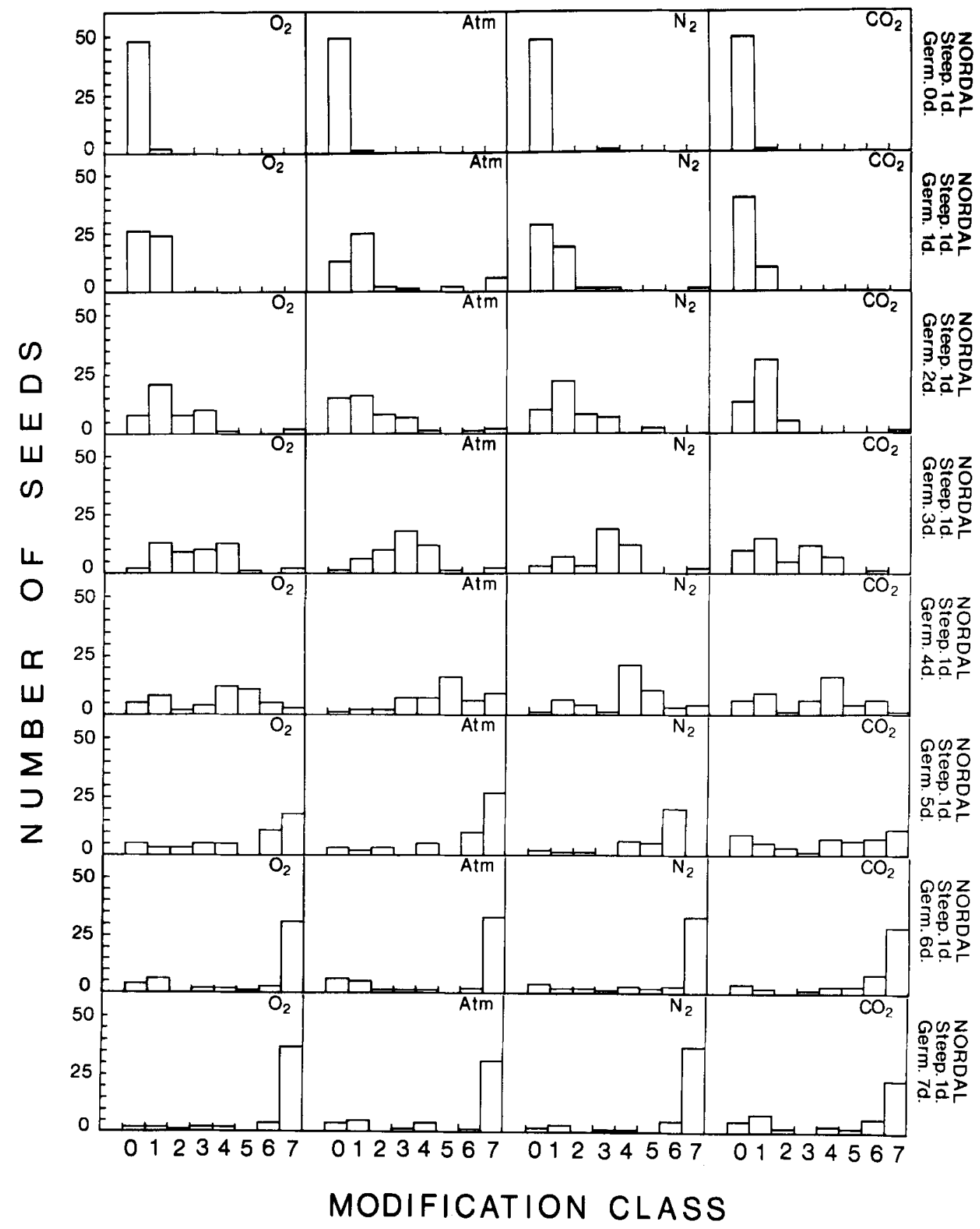

Figure 7. Modification of green malt of Nordal barley steeped in the presence of the described gasses $\left(\mathrm{O}_{2}=\right.$ oxygen, Atm = air, $\mathrm{N}_{2}=$ nitrogen, $\mathrm{CO}_{2}=$ carbon dioxide) for 1 day and germinated for a further 7 days with free access to air at $15{ }^{\circ} \mathrm{C} / 98 \%$ rh. The modification classes from 0 to 7 represent the number of seeds in the following classes: $0=$ unmodified; $1=0-20 \%$ modified; $2=20-40 \%$ modified; $3=40-60 \%$ modified; $4=60-80 \%$ modified; $5=80-95 \%$ modified; $6=95-99 \%$ modified; $7=100 \%$ modified. 


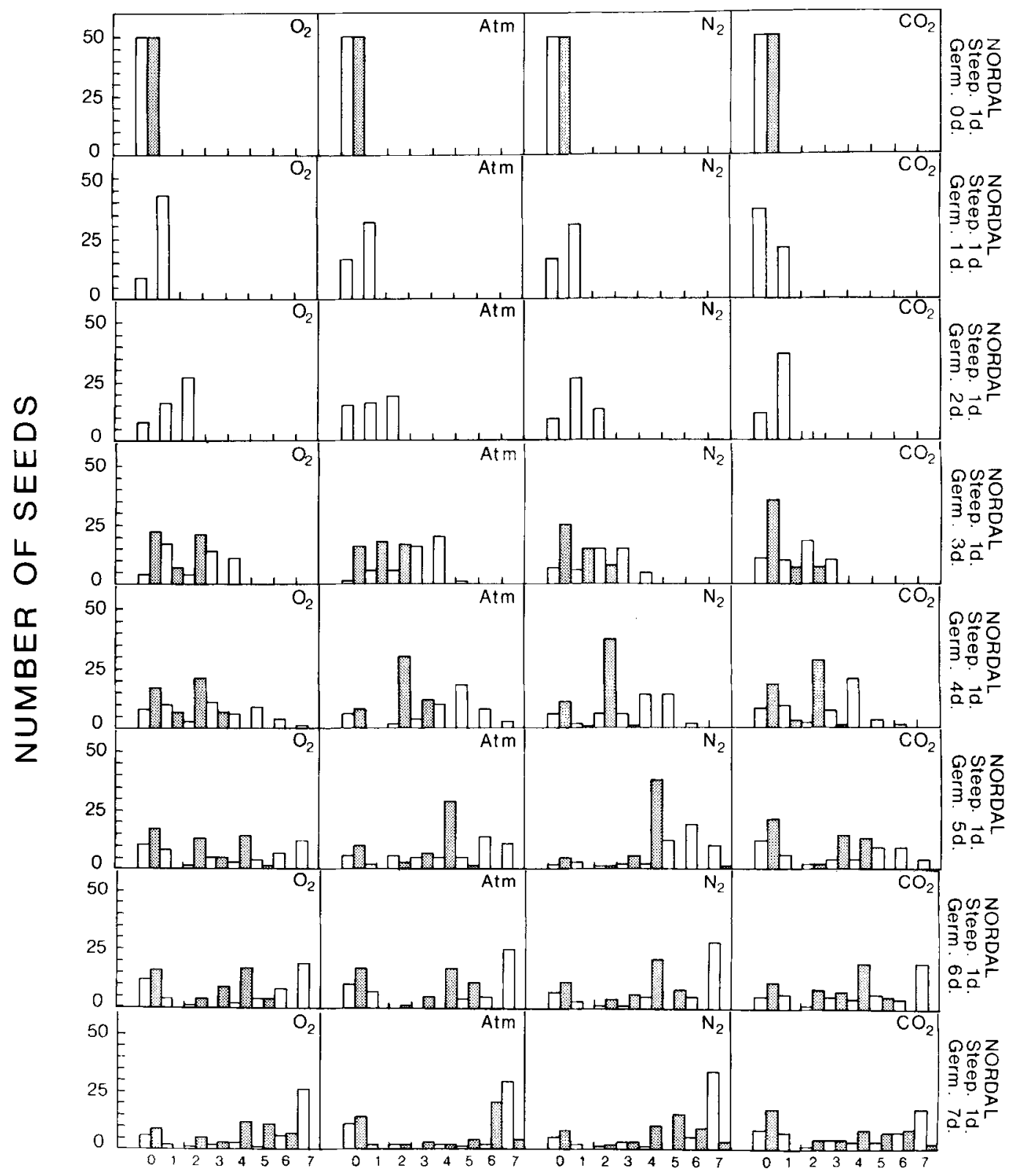

\section{ROOT or SHOOT LENGTH}

Figure 8. Embryo growth as measured by root and shoot length of Nordal barley steeped in the presence of the described gasses (for legend see Figure 7) for 1 day and germinated for a further 7 days with free access to air at 15 ${ }^{\circ} \mathrm{C} / 98 \%$ rh.

Roots (open columns) and shoots (shaded columns) were measured manually and the number of individual seeds with root or shoot lengths corresponding to the following defined length classes (0-7) plotted in their respective classes.

Class $0=$ no visible root or shoot $1=1-10 \mathrm{~mm}$ long; $2=11-20 \mathrm{~mm} ; 3=21-30 \mathrm{~mm} ; 4=31-40 \mathrm{~mm} ; 5=41-50 \mathrm{~mm} ; 6=$ $51-60 \mathrm{~mm} ; 7=$ greater than $60 \mathrm{~mm}$. 
G. C. GrbBons: $\mathrm{O}_{2} / \mathrm{N}_{2} / \mathrm{CO}_{2} /$ Air and Steeping

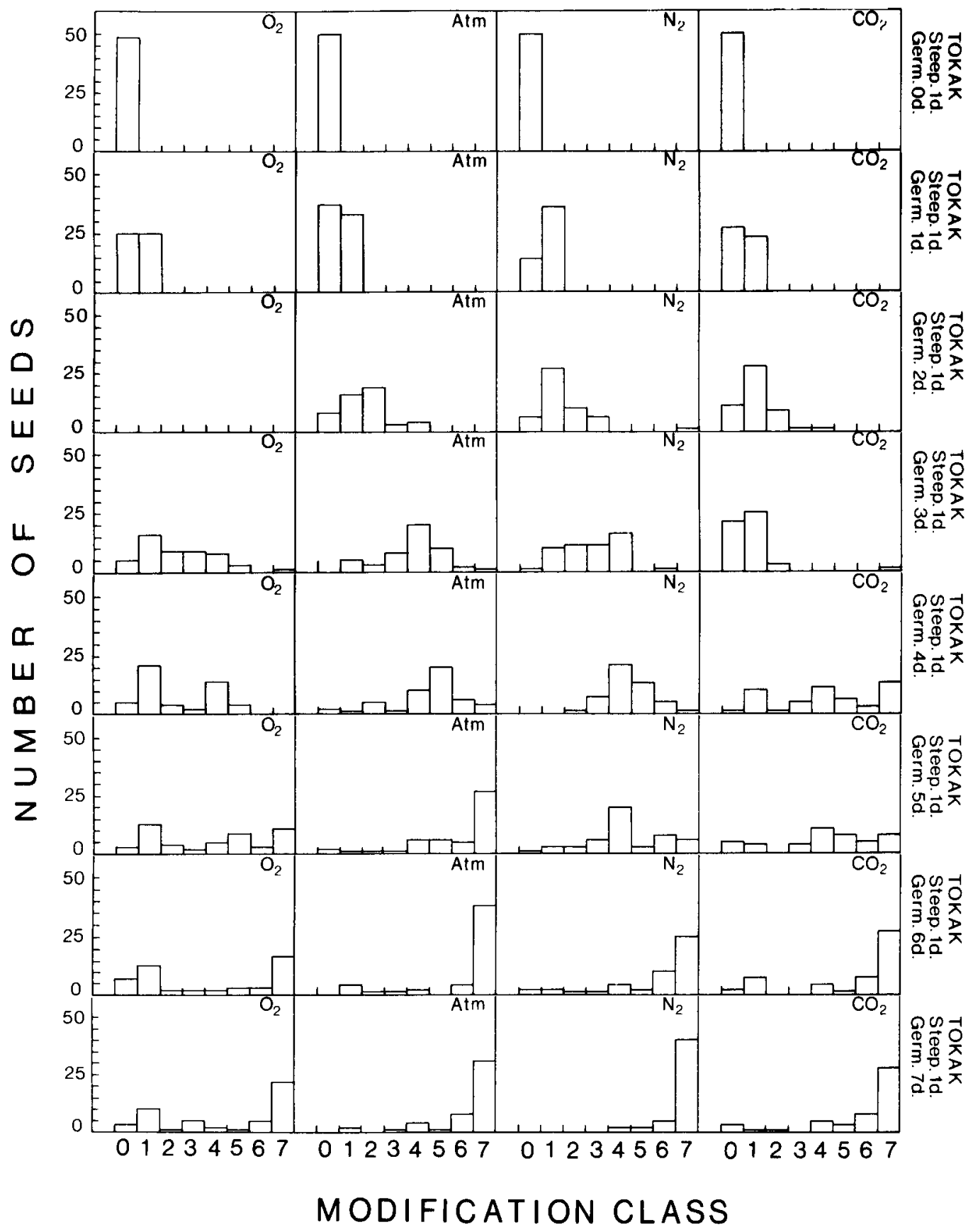

Figure 9. Modification of Tokak barley after 1 day steeping. For further legend see Figure 7. 


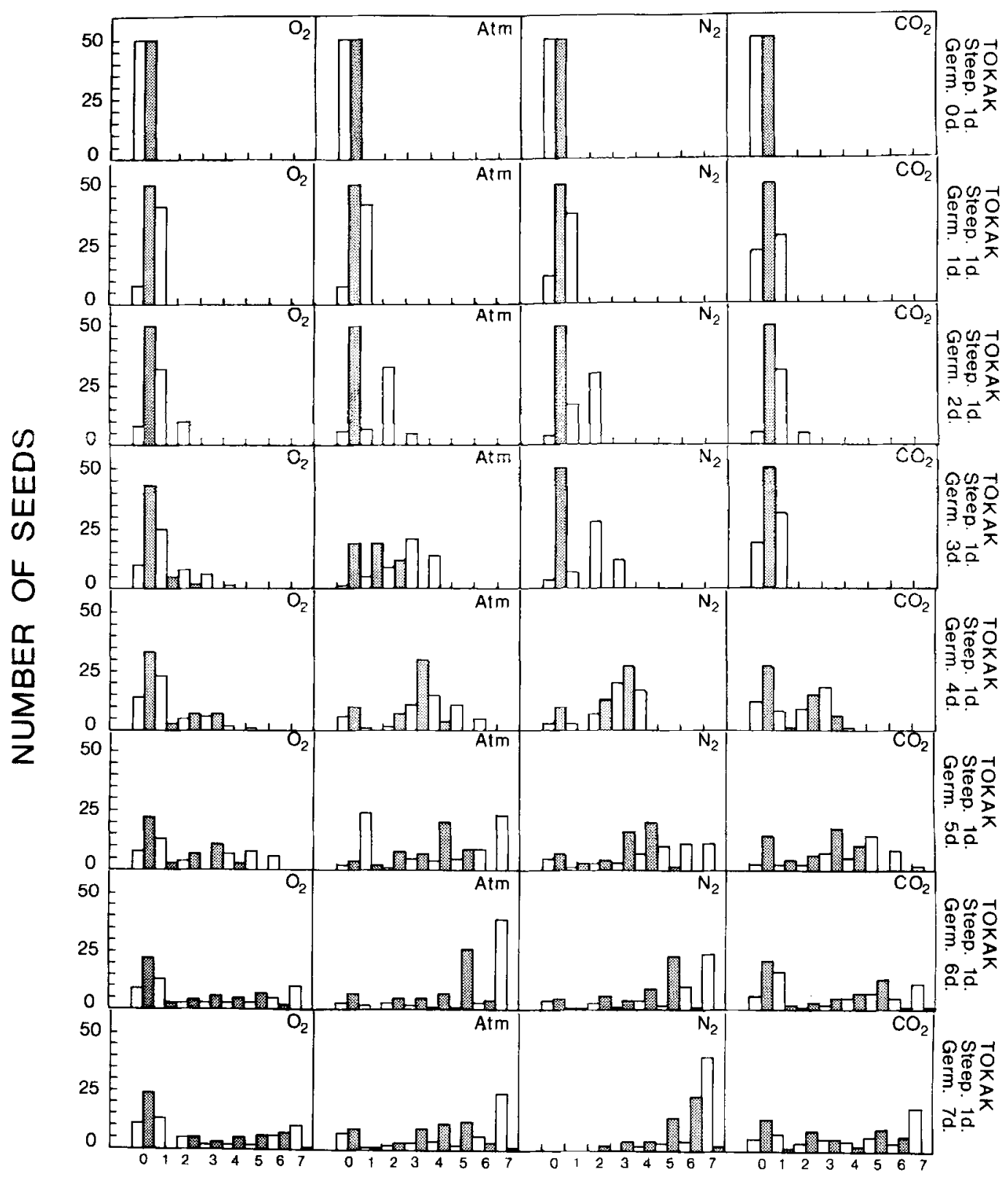

ROOT or SHOOT LENGTH

Figure 10. Root and shoot development of Tokak barley after 1 day steeping. For further legend see Figure 8. 


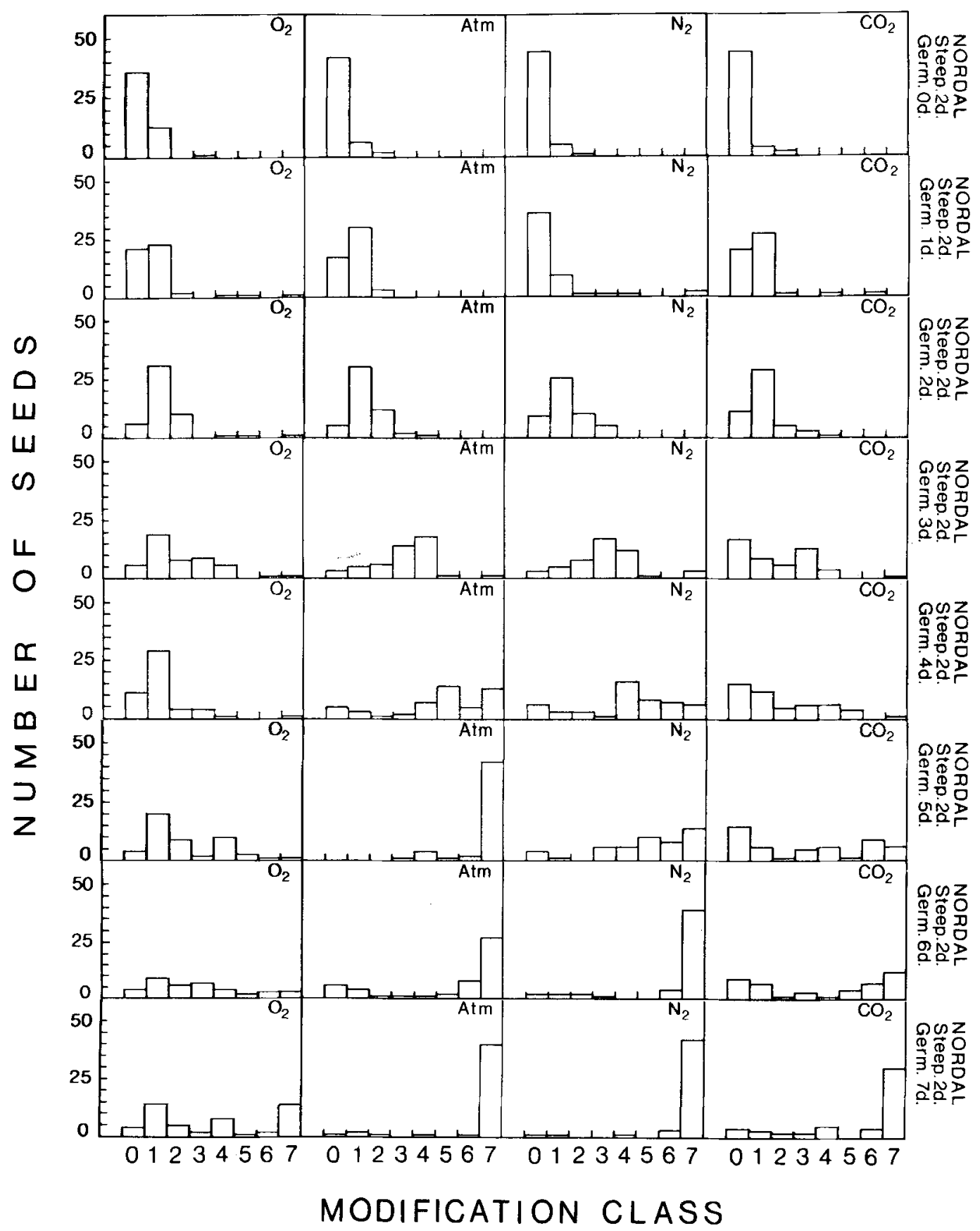

Figure 11. Modification of Nordal barley after 2 days steeping. For further legend see Figure 7. 


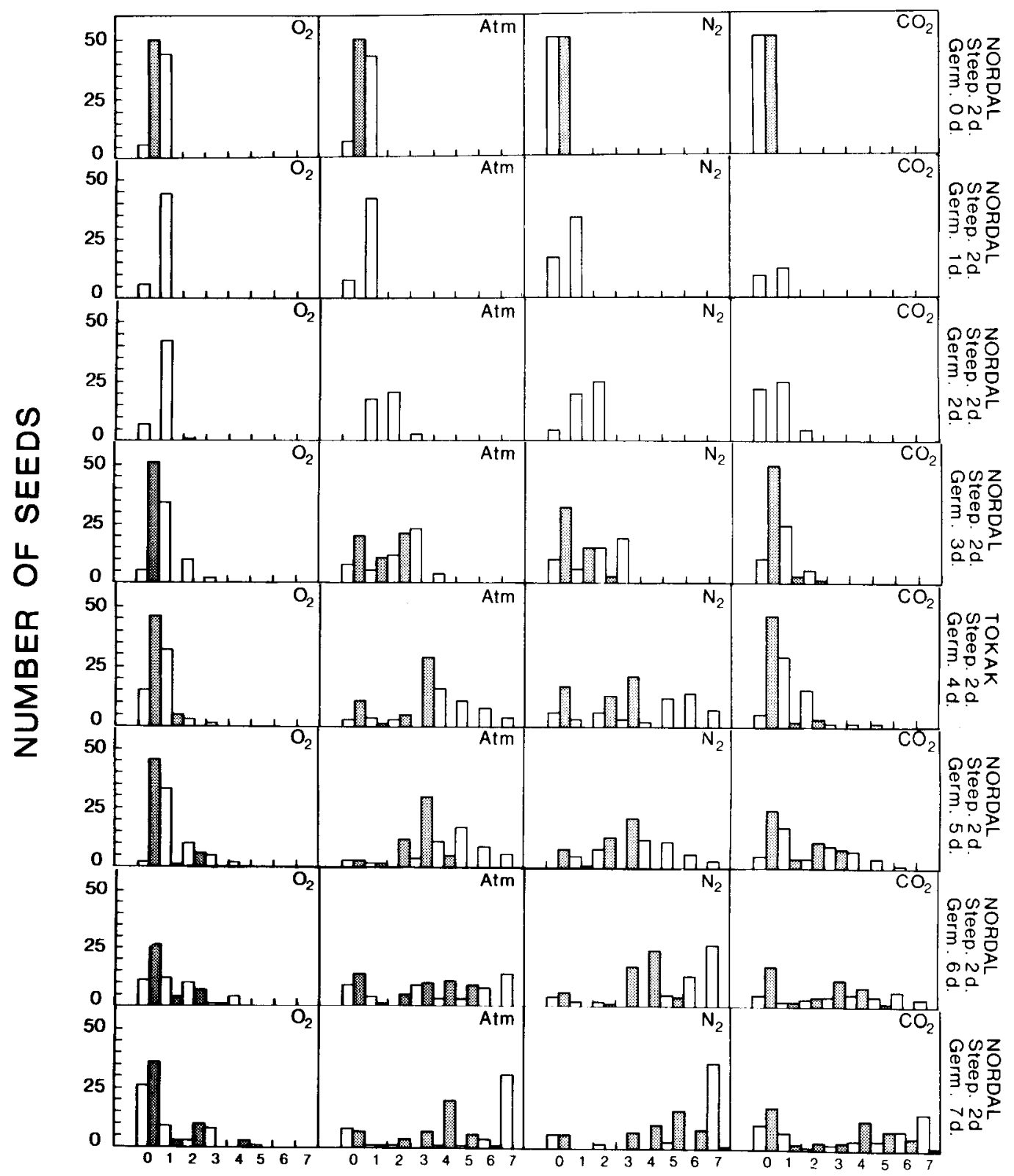

ROOT or SHOOT LENGTH

Figure 12. Root and shoot development of Nordal barley after 2 days steeping. For further legend see Figure 8. 
G. C. GibBons: $\mathrm{O}_{2} / \mathrm{N}_{2} / \mathrm{CO}_{2} /$ Air and Steeping

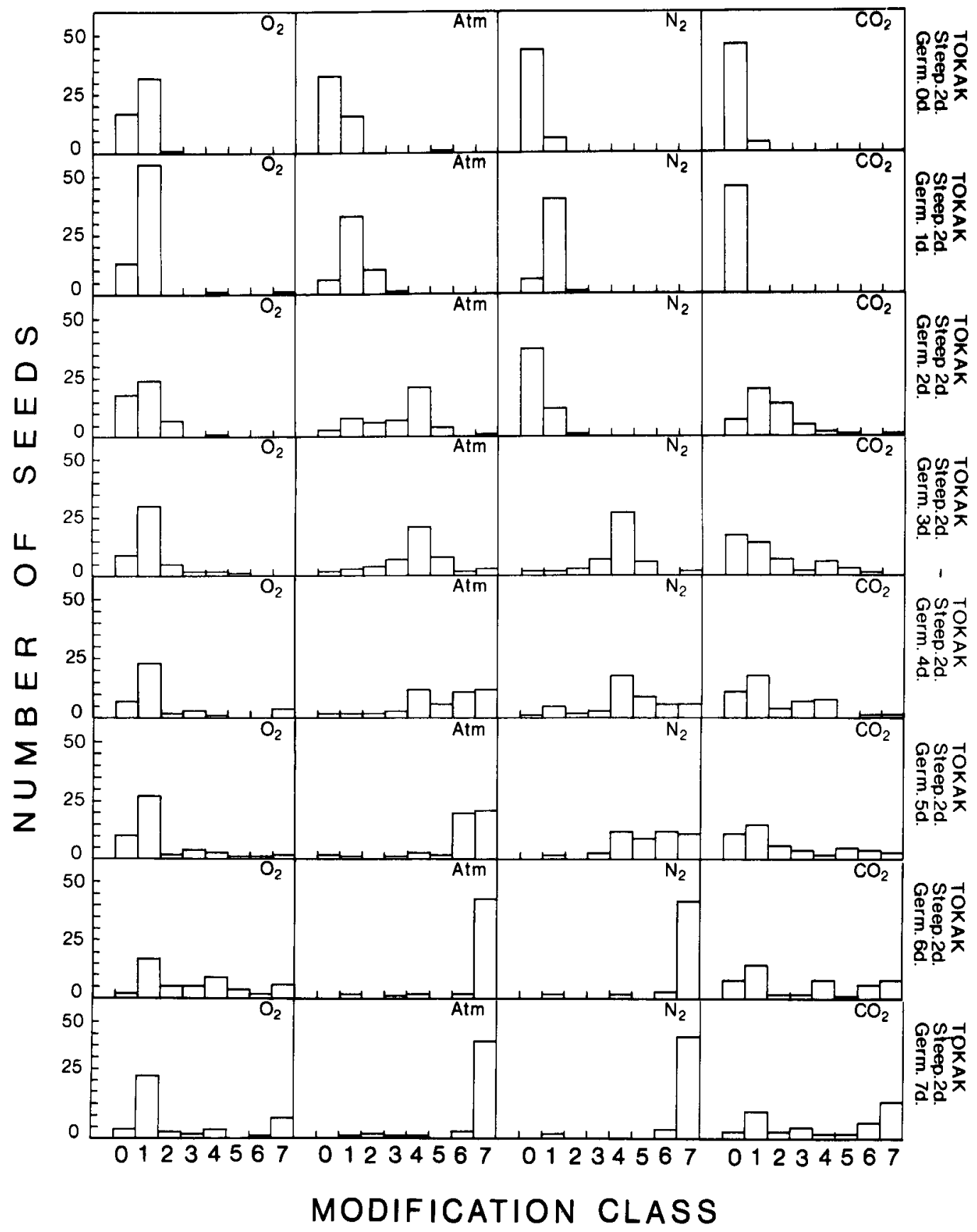

Figure 13. Modification of Tokak barley after 2 days steeping. For further legend see Figure 7. 


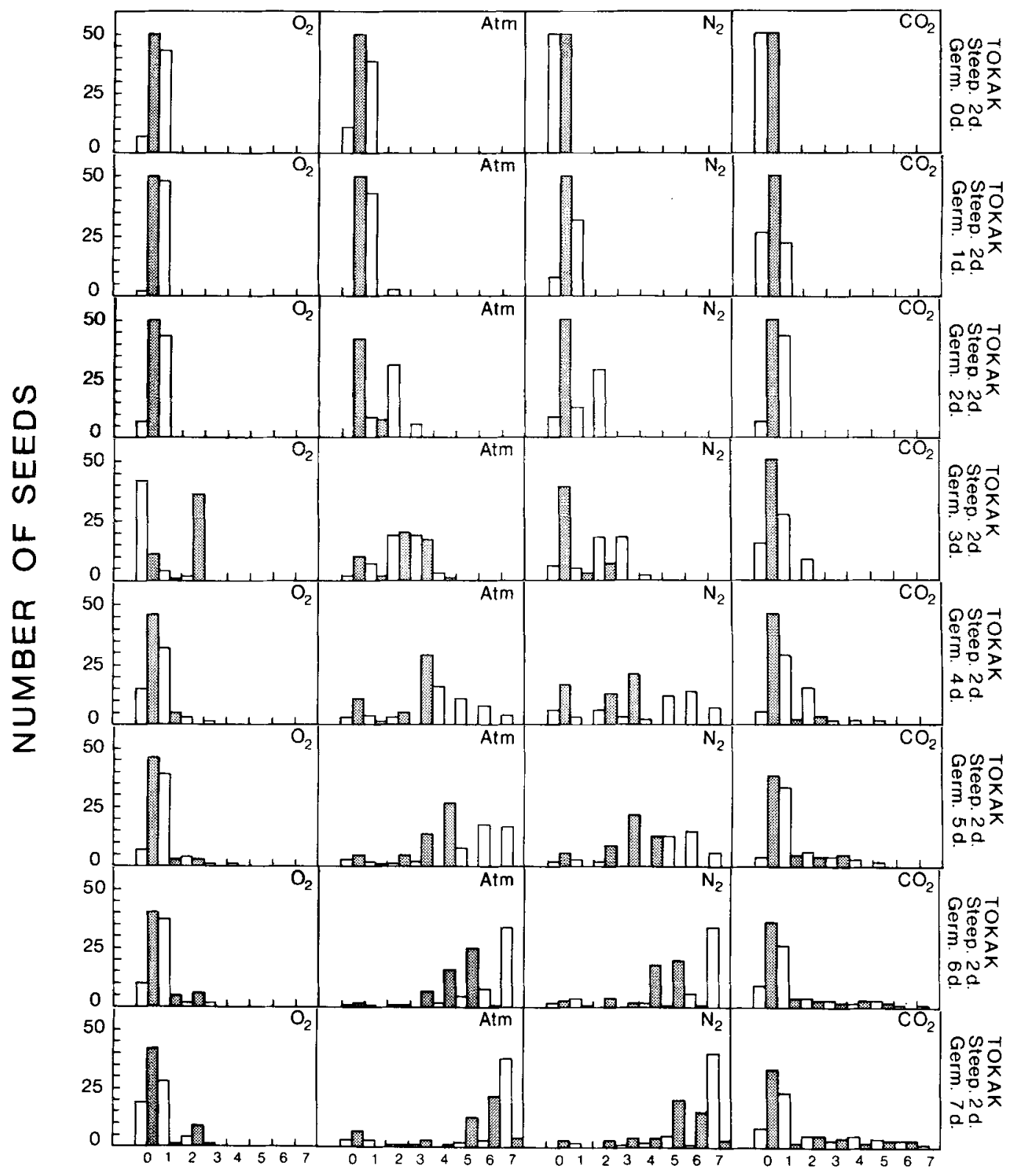

ROOT or SHOOT LENGTH

Figure 14. Root and shoot development of Tokak barley after 2 days steeping. For further legend see Figure 8 . 
G. C. Gibbons: $\mathrm{O}_{2} / \mathrm{N}_{2} / \mathrm{CO}_{2} /$ Air and Steeping

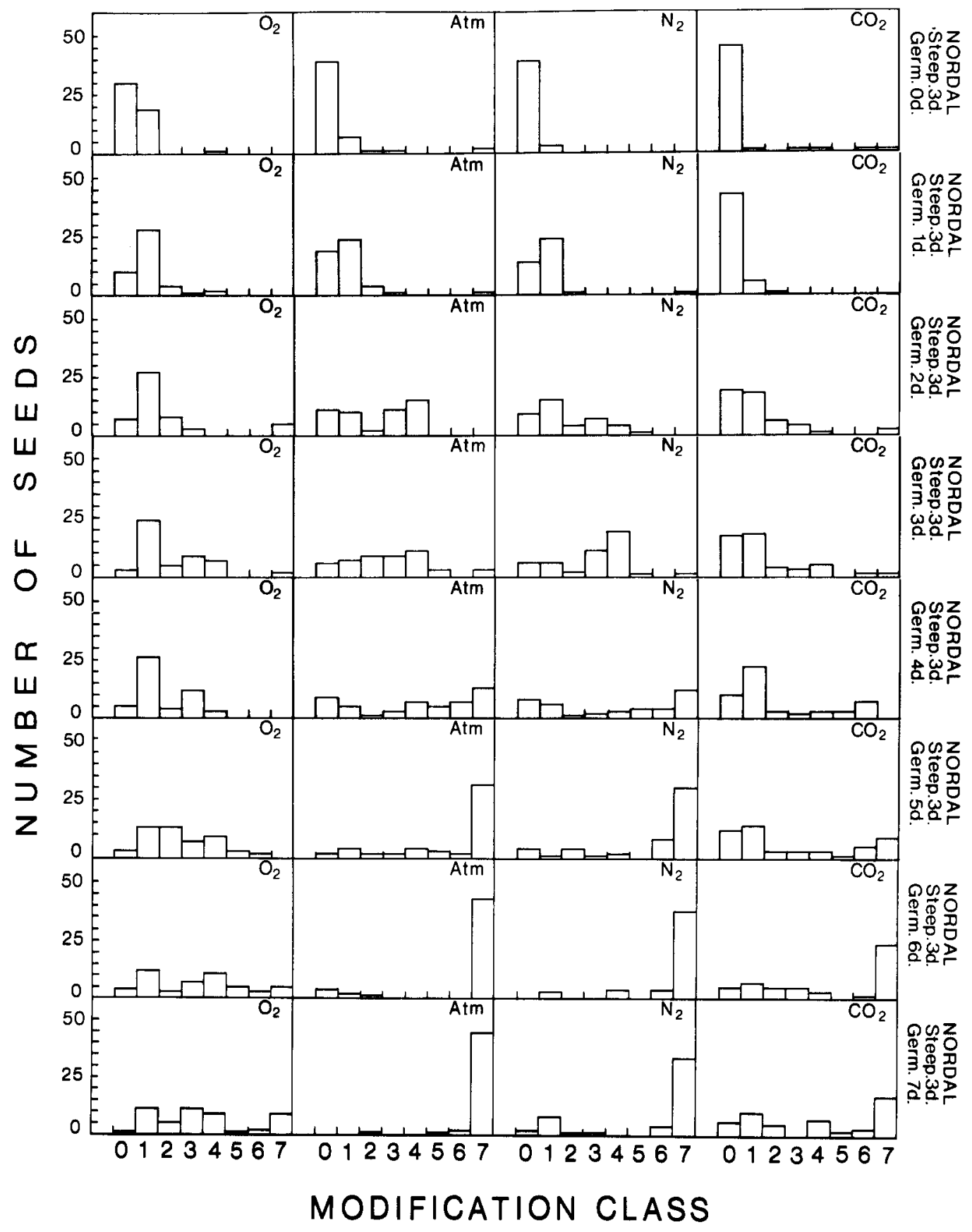

Figure 15. Modification of Nordal barley after 3 days steeping. For further legend see Figure 7. 
Carlsberg Res. Commun. Vol. 48, p. 35-56, 1983

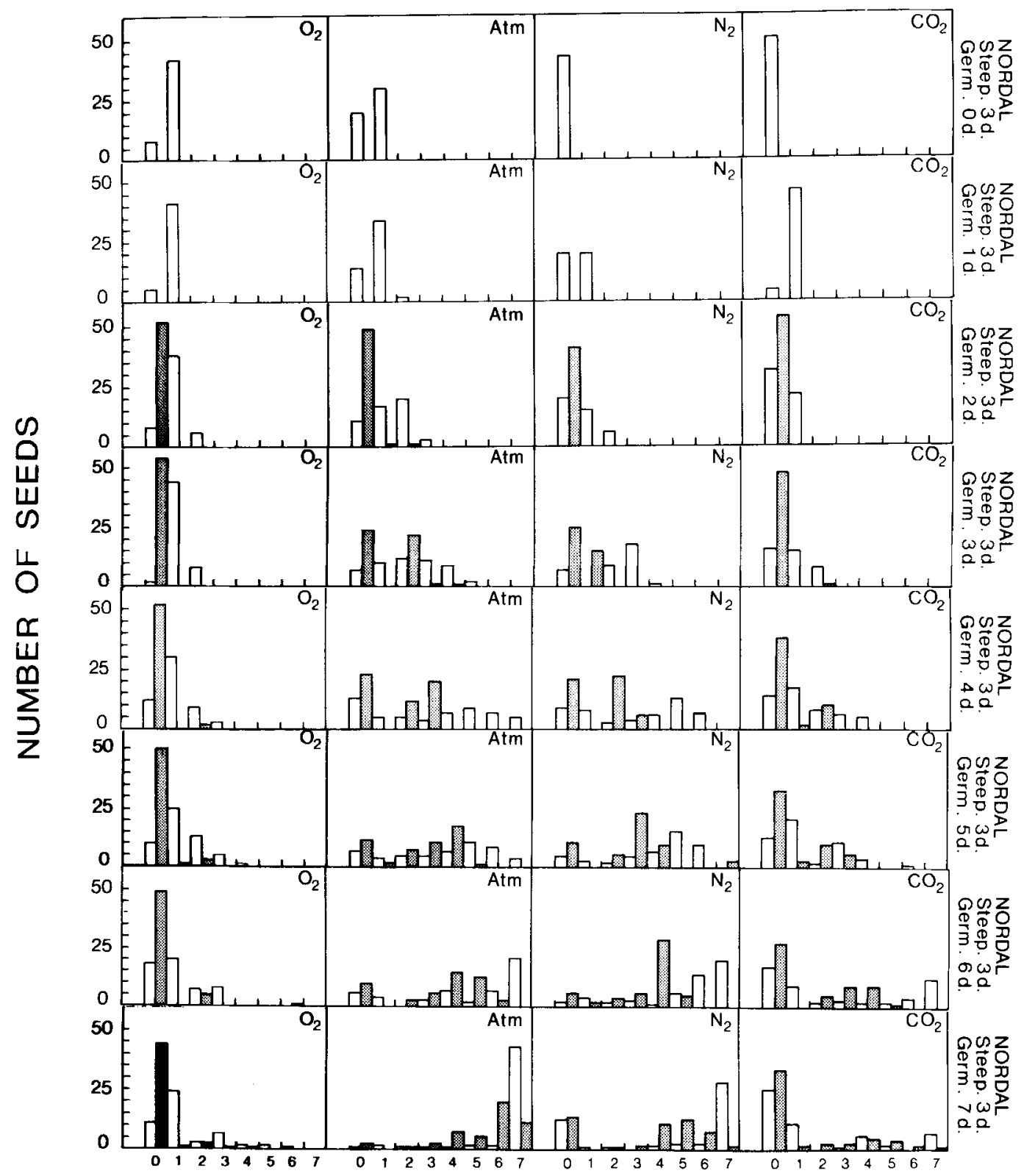

ROOT or SHOOT LENGTH

Figure 16. Root and shoot development of Nordal barley after 3 days steeping. For further legend see Figure 8 . 
G. C. Gibbons: $\mathrm{O}_{2} / \mathrm{N}_{2} / \mathrm{CO}_{2} /$ Air and Steeping

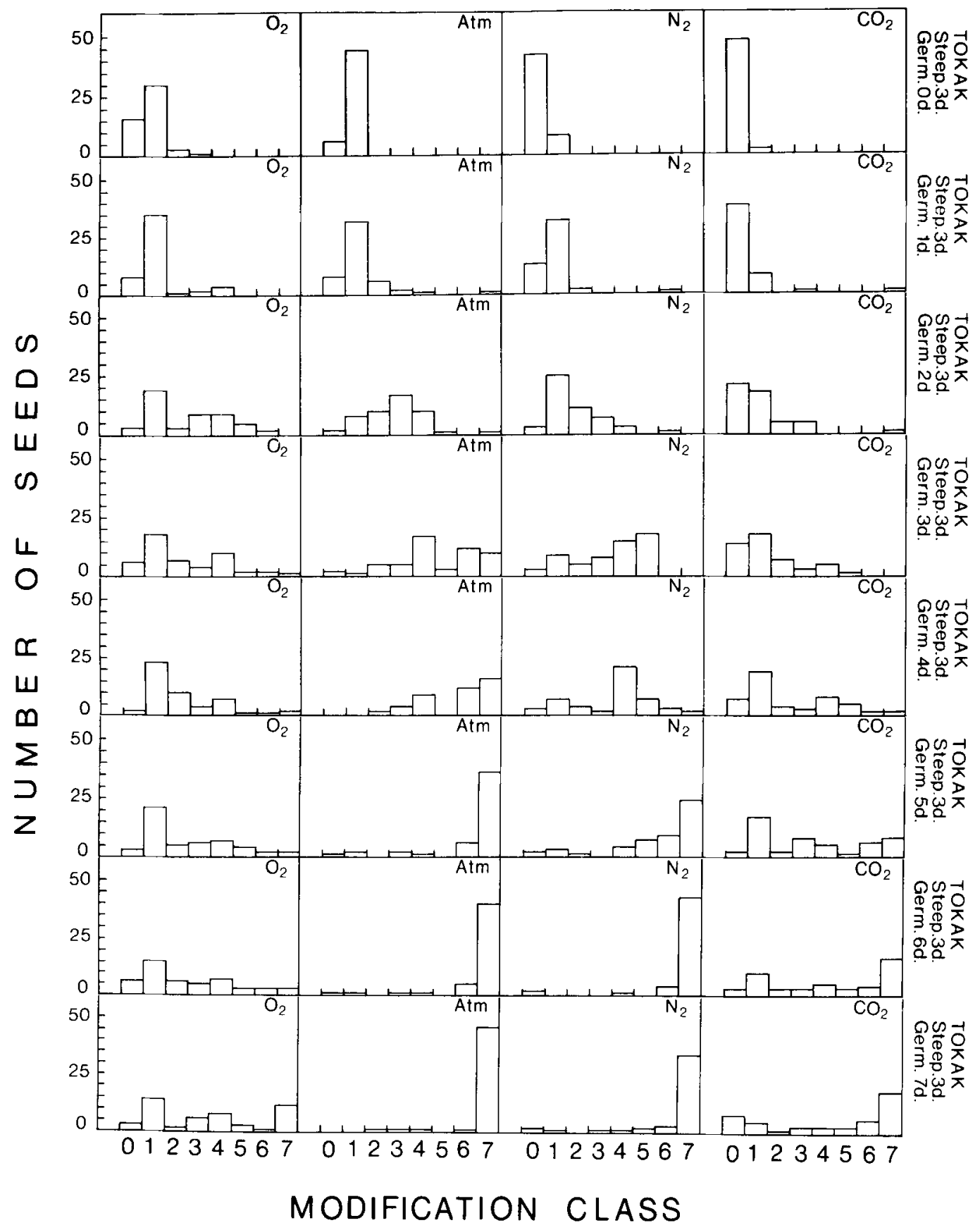

Figure 17. Modification of Tokak barley after 3 days steeping. For further legend see Figure 7. 
G. C. GibBons: $\mathrm{O}_{2} / \mathrm{N}_{2} / \mathrm{CO}_{2} /$ Air and Steeping

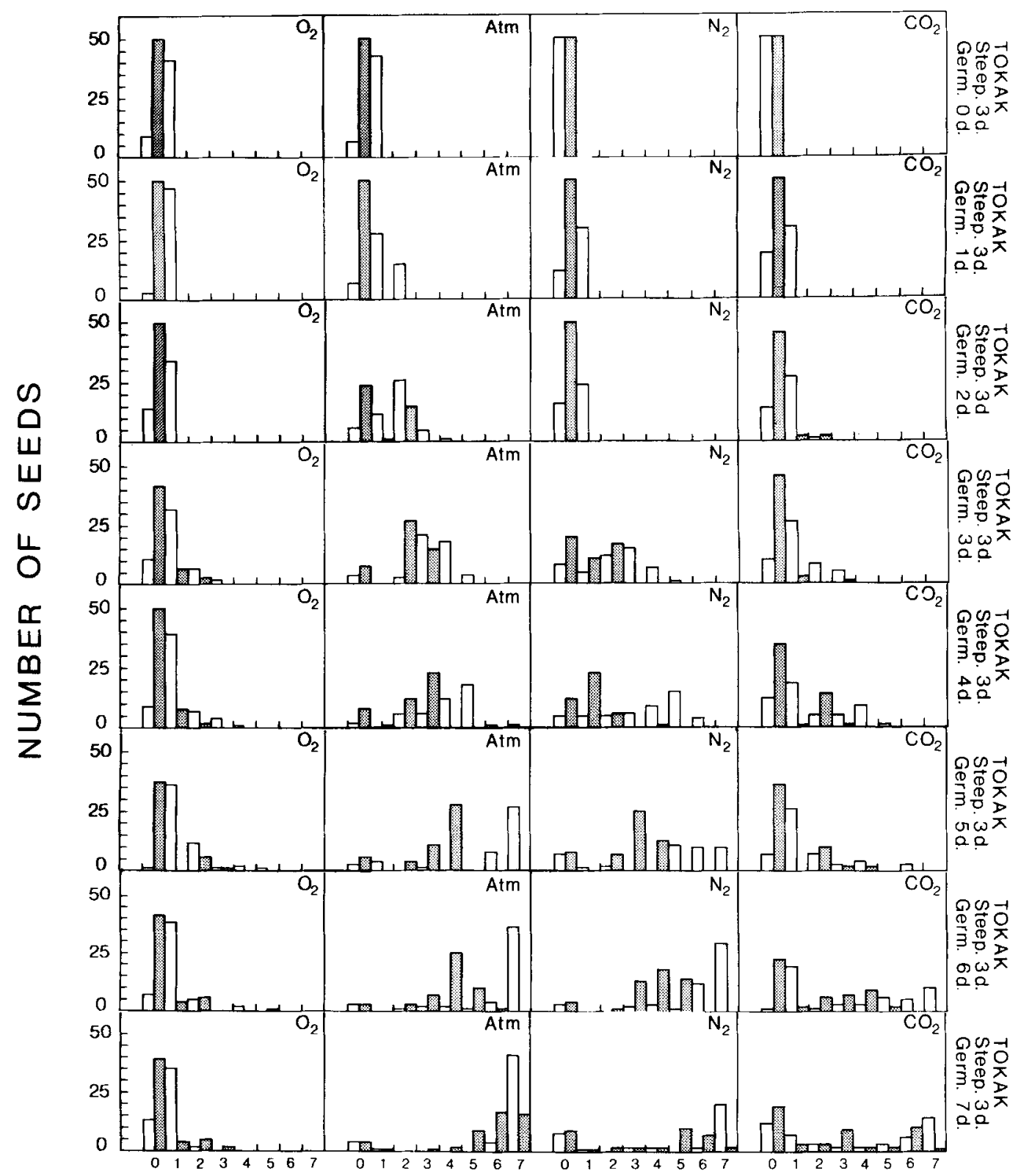

ROOT or SHOOT LENGTH

Figure 18. Root and shoot development of Tokak barley after 3 days steeping. For further legend see Figure 8 . 
embryo growth although in the $\mathrm{CO}_{2}$-treatment over $1 / 2$ of the population showed little or no embryonic activity.

\subsection{3 days steeping}

The initial out-of-steep moistures for both Nordal (Figure 5) and Tokak (Figure 6) were higher than for 2 days. It was now clearly observed that $\mathrm{CO}_{2}$-treatment during steeping increased the out-of-steep moisture content markedly in both varieties. Although the water content of the air- and $\mathrm{N}_{2}$-treatments increased in both varieties during germination, there were minimal changes in both the $\mathrm{O}_{2}$ - and $\mathrm{CO}_{2}$-steeped seeds' water content during subsequent germination on sand.

The out-of-steep modification for Nordal was highest in the $\mathrm{O}_{2}$-treated seeds followed by the air-treated, $\mathrm{N}_{2}$-treated and finally $\mathrm{CO}_{2}$-treated seeds which showed no out-of-steep modification at all (Figure 15). Once again the $\mathrm{O}_{2-}$ and $\mathrm{CO}_{2}$-steeping greatly inhibited further modification of the endosperm during germination. A lesser inhibitory action of $\mathrm{N}_{2}$-steeping is seen in this 3 days treatment.

Initial root growth for Nordal was also higher in the $\mathrm{O}_{2}$ - and air-treatments (Figure 16). $\mathrm{O}_{2}$ and $\mathrm{CO}_{2}$ again showed inhibition of root and shoot development. Lesser inhibition was also seen in the $\mathrm{N}_{2}$-steeped seeds.

Essentially the same results were found with the variety Tokak in terms of modification (Figure 17) and embryo development (Figure 18) i.e. higher out-of-steep modification and root development with $\mathrm{O}_{2}$ - and air-steeping; inhibition of both modification and embryo development with $\mathrm{O}_{2}$ - and $\mathrm{CO}_{2}$-steeping and a lesser degree of inhibition of these parameters following 3 days of $\mathrm{N}_{2}$-steeping.

From the data presented in Figures 8-18 it is possible to discern an effect of steeping time per se which is apparently independent of the gas treatment used. This effect, here defined as a "water effect", is clearly illustrated if data for one given processing time (steeping plus germination) is compared. Figures 19 and 20 are the results for modification and embryo growth respectively for both barley varieties in the case of a total processing time of 6 days.

Firstly, with regard to modification (Figure 19) it is seen that the inhibitory effect of $\mathrm{O}_{2}$ in the steep becomes greater and greater with increased exposure to this gas. The same is the case for $\mathrm{CO}_{2}$ while in the case of air and $\mathrm{N}_{2}$, the slowing down of the rate of modification with increased steeping time could well reflect some water effect per se.

Secondly, with regard to root and shoot development (Figure 20) it is seen that whilst the embryo can apparently overcome the inhibitory effects due to 1 day steeping in $\mathrm{O}_{2}$, longer exposure than 1 day has an irreversible effect. $\mathrm{CO}_{2}$ on the other hand, requires a longer time to excert its inhibitory action. The same applies to a lesser extent for $\mathrm{N}_{2}$ although it is difficult to discern an absolute $\mathrm{N}_{2}$-effect from a water effect which was also the case with endosperm modification seen in Figure 19.

The data presented in Figures 19 and 20 again serve to demonstrate that the atmospheric air and nitrogen treatments have similar, reversible effects on both modification and embryo growth parameters, whilst $\mathrm{O}_{2}$ and $\mathrm{CO}_{2}$ are indicative of a more toxic reaction on the seeds during steeping.

\section{DISCUSSION}

\subsection{Water uptake}

The initial effects of the employed gasses during steeping was seen on both initial water uptake and the further progress of water uptake during germination. The physiological and biochemical factors affecting water uptake have been previously studied in detail $(6,7,8,19)$ and the review by BroOKEs et al. (4) gives an excellent background for a discussion of this subject. These authors have considered water uptake to consist of three main phases: Phase 1, a period of rapid water uptake, generally considered to be a purely physical process; Phase 2, also referred to as the Baker-Dick break, in which water uptake is very slow or ceases completely; Phase 3 , in which water is taken up at a steady rate correlated with the rate of function of metabolic processes.

In the present experiment it was clearly seen that the initial out-of-steep moisture content of Nordal was higher than that of Tokak. This could be due to a number of physical and chemical differences between equalsized seeds of these varieties. Initial water content can affect the rate 


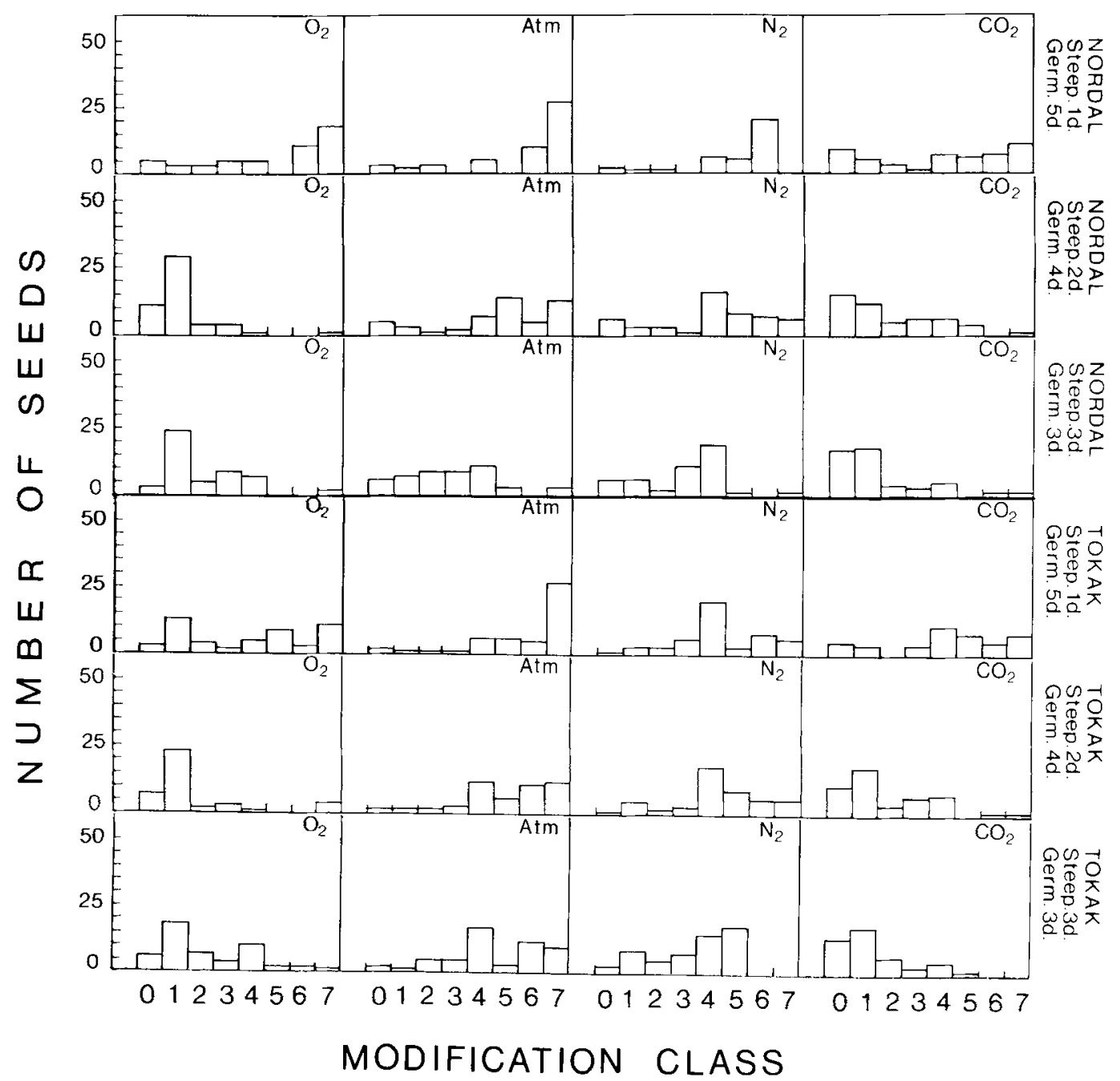

Figure 19. Comparison of endosperm modification in germinating seed of Nordal and Tokak barley after a total treatment time of 6 days (steeping plus germination). For further legend see Figure 7.

of water uptake, drier seeds generally requiring longer steeping times than those with a higher moisture content (4). In the present experiments, Nordal seeds had a moisture content of $10.7 \%$ and Tokak of 9.1\%. Equally Brookes et al. (4) refer to a number of authors who have provided evidence that lower nitrogen content tended to result in more rapid water uptake. The seeds of Nordal and Tokak used in these experiments contained $9.7 \%$ and $10.6 \%$ protein, respectively.

AASTRUP $(1,2)$ has recently shown that barley from drier climates tends to have higher viscosities of acid flour extracts and higher $\beta$-glucan contents, and that for the same variety an in- crease in $\beta$-glucan in the endosperm results in a slowing of the initial rate of water uptake. Therefore it could be expected that Tokak barley grown in the drier Turkish conditions would have a higher $\beta$-glucan content than Nordal grown in the wetter Danish environment. Viscosity analysis of the acid flour extract of seeds used in the present experiments confirmed this expectation. Using the method of AASTRUP (1), Tokak had an acid flour extract viscosity of 160 $\mathrm{cP}$, whilst Nordal extracts showed less than $2 \mathrm{cP}$. According to AASTRUP, a high viscosity of acid flour extract is significantly correlated with soluble $\beta$-glucan and with a lower correlation coeffi- 


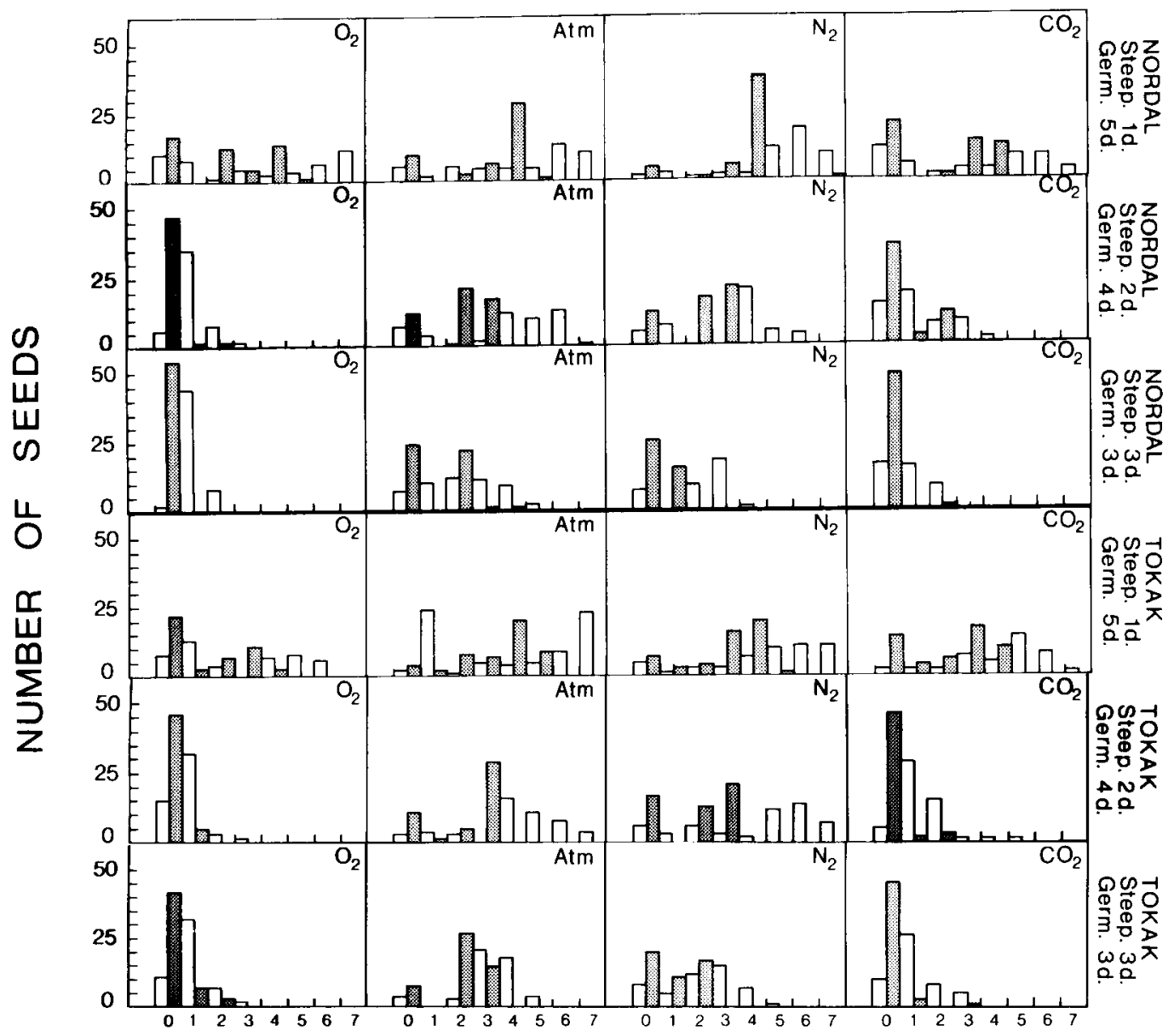

\section{ROOT or SHOOT LENGTH}

Fig. 20. Comparison of root and shoot development of Nordal and Tokak barley after a total treatment time of 6 days (steeping plus germination). For further legend see Figure 8.

cient to total $\beta$-glucan content. Total $\beta$-glucan analysis after (2) showed that Tokak contained $5.5 \% \beta$-glucan whilst the Nordal seed had only $3.6 \%$. It can be concluded that the low initial water content, the high protein content, the high total $\beta$-glucan, and the high acid flour extract viscosity of Tokak are all factors which could explain why Tokak is initially slower in water uptake and germination compared to Nordal.

The seed size effect mentioned by BROOKES et al. (4) in which larger corns absorb water more quickly initially, is negated by the fact that seeds of both varieties used in the present experiments were of same size.
It is interesting to note that Tokak appears more susceptible to the long term toxic effects of $\mathrm{CO}_{2}$ after only one day of steeping with this gas. In both varieties, however, $\mathrm{CO}_{2}$-treatment during steeping results in a higher initial moisture content, which may be a result of some $\mathrm{CO}_{2}$-effect on the permeability of the outer integuments of the grain.

The results of the experiments show that the presence of $\mathrm{O}_{2}$ and $\mathrm{CO}_{2}$ during the initial steeping period inhibits water uptake during subsequent germination on moist sand with free access to air. As the last phase of water uptake according to BrooKes et al. (4) is metabolically 
controlled and cannot be seen in dead grains or in grains germinated at low temperature, the present data would indicate that some irreversible metabolic changes have occurred during steeping with $\mathrm{O}_{2}$ or $\mathrm{CO}_{2}$, and that these changes are sufficient to retard water uptake under subsequent conditions which in themselves are not inhibitory. Nitrogen appears to have little effect when compared to atmospheric air, which suggests that initial anaerobic conditions per se do not inflict an absolute toxic effect on the germinatinggrain assuggested by other authors $(6,7)$.

\subsection{Modification}

Analysis of the endosperm modification data leads to the general conclusion that $\mathrm{O}_{2}$ and $\mathrm{CO}_{2}$ in the steep exert an irreversible toxic effect on modification while bubbling with either atmospheric air or nitrogen treatment of the steeps give very similar results. This indicates toxic effect of $\mathrm{O}_{2}$ or $\mathrm{CO}_{2}$ per se and in no way supports the theory that anaerobicity during steeping, with the resultant metabolic conversion of reserve carbohydrates to ethanol, is a condition to be avoided at all costs. On the other hand, removal of $\mathrm{CO}_{2}$ during steeping must be seen to be of utmost importance.

The toxic effects of $\mathrm{O}_{2}$ parallel the physiological effects of high concentrations of this gas on animals and humans (13) and are in practice of little relevance to the malster. Saturating or near saturating $\mathrm{CO}_{2}$-levels in both wet and dry steeps, are however commonly found in commercial maltings $(4,5,6,15,16,20)$.

The "water effect" seen in the results is also an inhibitory factor, but as seen with the $\mathrm{N}_{2}$ and atmospheric air treatment, fully reversible.

Modification during germination is seen to be highly dependent on the initial steeping conditions. Toxic agents viz. $\mathrm{O}_{2}$ and to a slightly lesser extent $\mathrm{CO}_{2}$, are seen to affect the seeds in such a way that they are subsequently unable to carry out the normal metabolic reactions required to modify the internal structure of the endosperm, even under conditions which are considered optimal for germination (sowing in moist sand with free access to air).

It should be noted that even under conditions where the starting seed material is very homogeneous (same variety, same years' harvest from the same area, defined grain size) there is variability in the reaction of the individual grains to steeping conditions. It was seen that even after three days steeping with $\mathrm{O}_{2}$ or $\mathrm{CO}_{2}$, there were seeds of both varieties that exhibited the same rate of modification as those treated with atmospheric air or $\mathrm{N}_{2}$. The physical conditions employed during steeping (relatively small number of seeds in a large vessel) were such that local effects would not be expected on the grains which could explain this variation. The only possible overriding explanation could be the presence of small cracks in the husk of a proportion of the seeds which would allow more rapid access of the gas employed during steeping.

\subsection{Embryo growth}

The results for the embryo growth parameters, root length and shoot length closely parallelled those for modification.

It is important to note that under the optimal germination conditions used here, root and shoot growth are favoured due to the constant presence of moisture in the sand. As such the conditions are different from the normal germination conditions in a traditional malthouse where the dry conditions inhibit embryo growth. Any positive or negative effects of the steeping period on roots or shoots, however, seen under the present steeping conditions are also expected to show the same tendencies in a commercial malthouse. Thus the initial stimulation in embryo growth during steeping in air is similar to effects seen by previous authors (5).

Comparison between the $\mathrm{CO}_{2}, \mathrm{~N}_{2}$, and air treatment showed that $\mathrm{CO}_{2}$ was not inert and resulted in a high degree of inhibition of embryo growth when compared to the anaerobic $\mathrm{N}_{2}$ treatment. $\mathrm{N}_{2}$ per se had little effect when compared with the air treatment and it can again be concluded that the expected anaerobic fermentation occurring in the seeds during $\mathrm{N}_{2}$-steeping did not produce products (i.e. ethanol) in sufficient quantities to assert toxic or inhibitory effects on the further growth of the embryo (cf. 6).

Finally it should be noted that REYNOLDS and MaCWILliam (19) showed that for a number of barley varieties, the major water uptake to the embryo occurs during the first 2 to 6 hours after 
wetting. As the present experiments show that marked inhibitory changes can occur during steeping which are subsequently found to inhibit both embryo growth and modification under otherwise optimal conditions for germination and growth, it appears necessary that the quality of the first steep water be closely controlled. In many commercial malthouses it is common to utilize saved spray water or saved steep water which is known to have a high $\mathrm{CO}_{2}$-content for the first steep.

\subsection{Conclusion}

There exists an old German brewer's and malster's expression "Das Malz wird in der Weiche gemacht", Malt is made in the steep (12). The results of the present investigation fully support this thought and further show that it is possible to influence the barley grains in such a way during steeping, that they remain permanently affected during subsequent germination periods under otherwise optimal conditions.

For the practical malster the present experimental evidence verifies that removal of carbon dioxide during steeping is more important than addition of oxygen.

\section{ACKNOWLEDGEMENT}

I would like to express my thanks to Ms. LISE Tang Petersen, Mr. Hans Peter Helt Hansen, and Ms. Anette Gliese Hansen for excellent technical assistance. Ms. UlLA-KARIN GibBONS is greatly thanked for drawing the figures and Ms. MetTe Høu for the photographic work. I am also indebted to Dr. LARS MUNCK for many stimulating discussions during the course of this work. Finally Ms. KIRSTEN KIRKEGAARD is thanked for typing the manuscript.

\section{REFERENCES}

1. Aastrup, S.: The effect of rain on $\beta$-glucan content in barley grains. Carlsberg Res. Commun. 44, 381-393 (1979)

2. Aastrup, S. \& K. ERdal: Quantitative determination of endosperm modification and its relationship to the content of $1,3: 1,4-\beta$-glucans during malting of barley. Carlsberg Res. Commun. 45, 369-379 (1980)

3. Aastrue, S., G.C. Gibbons \& L. Munck: A rapid method for estimating the degree of modification in barley malt by measurement of cell wall breakdown. Carlsberg Res. Commun. 46, 77-86 (1981)

4. Brookes, P.A., D.A. Lovett \& I.C. MaCWILLIAM: The steeping of barley. A review of the metabolic consequences of water uptake, and their practical implications. J. Inst. Brew. 82, 14-26 (1976)

5. Chambers, A.R. \& A.D.B. Lambie: Carbon dioxide and oxygen tensions in steep water. $J$. Inst. Brew. 66, 159-162 (1960)

6. Chapon, L.: Atmung und Gärung im geweichten Gerstenkorn. Ihr Einfluss auf die Keimung. Brauwissensch. 14, 457-465 (1961)

7. Enari, T-M., T. Linnahalme \& M. Linko: Effects of air and carbon dioxide in the steeping of barley. J. Inst. Brew. 67, 358-361 (1961)

8. GibBons, G.C.: On the localization and transport of $x$-amylase during germination and early seedling growth of hordeum vulgare. Carlsberg Res. Commun. 44, 353-366 (1979)

9. GibBons, G.C.: On the relative role of the scutellum and aleurone in the production of hydrolases during germination of barley. Carlsberg Res. Commun. 46, 215-225 (1981)

10. Gibsons, G.C.: On the sequential determination of $x$-amylase transport and cell wall breakdown in germinating seeds of Hordeum vulgare. Carlsberg Res. Commun. 45, 117-184 (1980)

11. GibBons, G.C.: Visualization of $\alpha$-amylase movement and cell wall breakdown during barley malting - Practical application of current research. J. Am. Soc. Brew. Chem. 39, 5559 (1981)

12. GloetzL, J: Über naturgemässes Gerstenweichen. Brauwelt. 100, 876-880 (1960)

13. HAKIM, J. \& M. TORRES: Forward to international conference on molecular mechanisms of oxygen toxicity. Bull. Europ. Physiopath. resp. 17 (suppl.), 7-8 (1981)

14. Heltved, F., S. Aastrup, O. Jensen, G.C. GibBONS \& L. Munck: Preparation of seeds for mass screening. Carlsberg Res. Commun. 47, 291-296 (1982)

15. KLEber, W., U.D. Runkel \& W. SteinhofF: Über die Entwicklung und Abführung von $\mathrm{CO}_{2}$ während des Weichens von Gerste. Brauwissensch. 14, 159-162 (1961)

16. MACEY, A.: Recent advances in malting ... with special reference to steeping. Brewers Digest, 35, 49-53, 70 (1960)

17. Munck, L., G.C. Gibbons \& S. Aastrup: Chemical and structural changes during malting. Proc. Eur. Brew. Conv. Copenhagen, 11-30 (1981) 


\section{G. C. Gibbons: $\mathrm{O}_{2} / \mathrm{N}_{2} / \mathrm{CO}_{2} /$ Air and Steeping}

18. NARZISS, L. \& H. KIENINGER: Zusammenhänge zwischen Wasseraufnahmegeschwindigkeit und Malzlösung. Brauwissensch. 19, 343-352 (1966)

19. Reynolds, T. \& I.C. MaCWilliam: Water uptake and enzymic activity during steeping of barley. J. Inst. Brew. 72, 166-170 (1966)
20. Weith, L. \& H. Kiaushofer: Studien zur Technologie der Mälzeri. IV. Belüftung und Enzymaktivität. Mitt. Versuchsstation f.d. Gärungsgewerbe Wien, 15, 141-150(1961) 